\title{
THE INFLUENCE OF PUBLIC PHYSICAL EDUCATION CURRICULUM ON COLLEGE STUDENTS' PHYSICAL HEALTH
}

\section{EFECTOS DE LOS PROGRAMAS DE EDUCACIÓN FÍSICA PÚBLICA EN LA SALUD FÍSICA DE LOSESTUDIANTES}

\author{
Youfeng Yang ${ }^{1}$ (ID \\ (Public Health) \\ Wei Liư 2,3 \\ (Basic Medicine)
}

1. Sport and Health College of Heze University, Heze, Shandong, 274015, China.

2. Shanghai University of Sport,

Shanghai, 200438, China.

3. Anhui water Conservancy

Technical College, Hefei, 231603, China.

\section{Correspondence:}

Siping 136000, Jilin, China.

hvjkff@163.com

\begin{abstract}
It is particularly important to improve the quality of physical education curriculum and the overall health level of college students. It is difficult to achieve a comprehensive evaluation of the original evaluation method of students' physical health level. Therefore, this study combined the analytic hierarchy process (AHP) and physical fitness training mode to build a university physical health evaluation model. Taking X University as the experimental background, 20 students of different majors in grade 2019 were selected as experimental objects. One group (10 students) adopted the original physical education curriculum mode, and the other group (10 students) integrated physical fitness training into the physical education curriculum. Using the established health evaluation model, the evaluation scores of physical health level of two groups of college students before and after the experiment were comprehensively analyzed. The results showed that the overall score of group A students' physical health level increased; the rising rate was 2.87\%. However, there was no significant change in the scores of physical health assessment of group $B$ students. The results show that physical fitness training into the public physical education curriculum can effectively help improve the overall health level of students, and also shows that the introduction of AHP into the evaluation of College Students' physical health level can improve the comprehensiveness of health level analysis. It is hoped that this study can provide some reference for physical education teaching in Colleges and universities, so as to improve the overall teaching level of colleges and universities.
\end{abstract}

Keywords: Physical health; physical fitness; physical education; analytic hierarchy process.

\section{RESUMO}

É particularmente importante melhorar a qualidade dos programas de educação física e o nível geral de saúde dos estudantes universitários. É difícil obter uma avaliação abrangente do método de avaliação inicial do nível de saúde física dos estudantes. Por conseguinte, este estudo combinou o processo hierárquico analítico (AHP) e o modo de condicionamento físico para construir um modelo universitário de avaliação da saúde física. Tendo a Universidade X como objeto experimental, vinte estudantes de diferentes especializações do período de 2019 foram selecionados como objetos experimentais. Um grupo (de dez estudantes) adotou o modo de educação física original, e o outro grupo (de dez estudantes) integrou o condicionamento físico no currículo de educação física. Utilizando o modelo estabelecido de avaliação da saúde, as pontuações de avaliação do nível de saúde física de dois grupos de estudantes universitários antes e depois do experimento foram exaustivamente analisadas. Os resultados mostraram que a pontuação global do nível de saúde física de um grupo de estudantes aumentou. A taxa de aumento foi de $2.87 \%$. No entanto, não houve alterações significativas nas pontuações da avaliação para a saúde física dos estudantes do grupo B. Os resultados mostram que o condicionamento físico no currículo público de educação física pode contribuir efetivamente para melhorar o nivel geral de saúde dos estudantes, e também mostra que a introdução do processo hierárquico analítico (AHP) na avaliação do nível de saúde física dos estudantes universitários pode melhorar a abrangência da análise do nivel de saúde. Espera-se que este estudo possa fornecer uma referência para o ensino de educação física nos colégios e universidades a fim de melhorar o nível de ensino geral das universidades.

Descritores: Saúde física; condicionamento físico; educação física; processo hierárquico analítico.

\section{RESUMEN}

Es particularmente importante mejorar la calidad del plan de estudios de educación física y el nivel de salud general de los estudiantes universitarios. Es difícil lograr un análisis integral del método de evaluación original del nivel de salud física de los estudiantes. Por lo tanto, este estudio combinó el proceso de jerarquía analítica (PJA) y el modo de entrenamiento de aptitud física para construir un modelo universitario de evaluación de la salud física. Tomando la Universidad X como base experimental, se seleccionaron como sujetos experimentales 20 estudiantes de diferentes carreras en los cursos de 2019. Un grupo (10 estudiantes) adoptó el modo de plan de estudios de educación física original y el otro grupo (10 estudiantes) integró el entrenamiento de aptitud física en el plan de estudios de educación física. Utilizando el modelo de evaluación de salud establecido, se analizaron exhaustivamente los puntajes de evaluación del nivel de salud física de los dos grupos de estudiantes 
universitarios antes y después del experimento. Los resultados mostraron que el puntaje general del nivel de salud física de los estudiantes del grupo A aumentó; la tasa de incremento fue del 2,87\%. Sin embargo, no hubo cambios significativos en las puntuaciones de la evaluación de la salud física de los estudiantes del grupo B. Los resultados muestran que el entrenamiento de la aptitud física en el plan de estudios público de educación física puede ayudar de manera efectiva a mejorar el nivel de salud general de los estudiantes y también muestra que la introducción de PJA en la evaluación del nivel de salud física de los estudiantes universitarios puede mejorar la precisión del análisis del nivel de salud. Esperamos que este estudio pueda proporcionar una referencia para la enseñanza de la educación física en los colegios y universidades, a fin de mejorar su nivel general en estos establecimientos.

\section{Descriptores: Salud física; deportes; análisis de niveles.}

\section{INTRODUCTION}

College students are the pillars of our country in the future, and their physical health has always been a concern. With the rapid spread of fitness training mode in the international scope, people in various countries have begun to realize the advantages of physical fitness training in human exercise, so fitness training with special guidance has become popular in various countries. ${ }^{1}$ Previous studies have shown that physical fitness training has a good effect in improving body fat content, cardiopulmonary endurance, muscle endurance and strength, and different training plans can be formulated for groups with different physical characteristics in the training process. ${ }^{2}$ However, physical fitness training needs special training equipment and professional coaches for guidance, and in the whole process of physical fitness training, it is also necessary to monitor the physical condition of the trainer from time to time. Physical fitness training needs harsh conditions and environment, so that physical fitness training mode can only be popularized in some economically developed areas. Therefore, due to the unbalanced development of economic level and regional cultural differences, the introduction of physical fitness training mode in college physical education curriculum needs researchers from different countries and regions to conduct a comprehensive and comprehensive study according to the physical education curriculum development of local college students and the overall physical health level of school students Analysis of the research. In this study, the analytic hierarchy process (AHP) will be used to analyze and compare the impact of physical fitness into college physical education public curriculum on students' physical health.

Wilks C R et al. used SF-12 health survey to analyze the relationship between College Students' physical and mental health problems and academic role function in self-report, and found that the reason for the high incidence of College Students' mental health problems is directly related to their learning role. ${ }^{3}$ The waure CD team investigated and studied the problems affecting the health of college students. ${ }^{4}$ Through the corresponding data analysis, it was found that the lack of physical exercise and irregular diet will make college students gain weight and cause obesity, thus increasing the risk of disease. Therefore, these factors are important factors affecting the health of College Students. Martinez YTS and his research team work together to study and understand the perception barriers of college students, understand and analyze the qualitative factors of students in various aspects by means of questionnaire, and finally form a comprehensive evaluation of the perception ability of different college students. The overall results show that the perceived barriers of college students are related to the quality of facilities and time cost. ${ }^{5}$ Peer J W et al. systematically studied the learning and life status of College Students under pressure. The results of qualitative analysis show that stress can affect students' learning, life and physical health in two ways: positive and negative. ${ }^{6}$
Therefore, this study considers the introduction of analytic hierarchy process (AHP) to analyze the impact of physical fitness training on College Students' physical health.

\section{The evaluation model is used to analyze and process the change data of health level}

According to the data of $X$ university students' physical examination database, 20 students with similar physical test scores in grade 2019 were selected as the experimental objects $(P>0.05)$. The 20 students were randomly divided into two groups, group $A$ and group $B$, with 10 students in each group. The students in the two groups were numbered a1-a10 and b1-b10 respectively. Group a students will have professional fitness training teachers to guide them to enter various fitness training projects. Group B still adopts the original teaching mode of the school. The experimental time is 8 weeks before the first half of the semester from 2019 to 2020. The experimental sites are $X$ university gymnasium and track and field playground. Before the beginning of the experiment, all the students were tested and the data were recorded. At the same time, we plan and design all the physical education courses of every week for all students, as shown in the Table 1.

According to the schedule of the above table, the two groups of students were trained and taught. After the experiment, the data of each index of the students were tested and counted again. Under the evaluation and guidance of experts, the data before and after the experiment were expressed in the form of 100 points. Using the college students' physical health test evaluation model established above, the weight of each index is brought into the evaluation score to calculate, and the total score of each student's physical health evaluation before and after the experiment is obtained. The results are shown in Table 2.

According to the data in the table, it can be preliminarily judged that the BMI index, cardiopulmonary function and other index scores of group a students with physical fitness training showed a certain upward trend. However, using the total score to evaluate, it is unable to make a comprehensive comparative evaluation of students' physical health level with the same score. Combined with the analytic hierarchy process model and weight, the result data can be analyzed comprehensively. In order to make the results more clear, the experiment combined with the score data to draw a broken line chart of the score changes of the two groups of students before and after the experiment, as shown in Figure 1.

In Figure 1, (a) is the comparison chart of the physical health evaluation scores of group a students before and after the experiment, and (b) is the comparison chart of the physical health evaluation scores of group $B$ students trained according to the routine physical education curriculum before and after the experiment. After comprehensive analysis of the two charts, it can be found that the physical fitness score of each student in group a increased significantly after physical fitness training, and the average increase rate was $2.87 \%$. Compared with the broken line chart of group B, according to the normal physical education curriculum, the 
Table 1. Physical education training plan.

\begin{tabular}{|c|c|c|c|}
\hline Week & & Group A & Group B \\
\hline \multirow{4}{*}{1} & \multirow{3}{*}{$\begin{array}{c}\text { Physical fitness } \\
\text { training }\end{array}$} & $60 \mathrm{~m}$ turn back: 4 groups & \multirow{3}{*}{ / } \\
\hline & & $\begin{array}{l}\text { Leg strength training, hamstring } \\
\text { group training: } 20 * 6 \text { groups }\end{array}$ & \\
\hline & & Push ups: $12 * 6$ groups & \\
\hline & $\begin{array}{l}\text { Classroom } \\
\text { content }\end{array}$ & Warm up gymnastics, basketball & $\begin{array}{l}\text { Warm up } \\
\text { gymnastics, } \\
\text { basketball }\end{array}$ \\
\hline \multirow{4}{*}{2} & & One minute step change: 90 seconds & \multirow{3}{*}{ / } \\
\hline & Pnysical titness & Push ups: $12 * 6$ groups & \\
\hline & & Suspension leg lift: $10 * 4$ groups & \\
\hline & $\begin{array}{c}\text { Classroom } \\
\text { content }\end{array}$ & Warm up gymnastics, football & $\begin{array}{c}\text { Warm up } \\
\text { gymnastics, football }\end{array}$ \\
\hline \multirow{4}{*}{3} & & Fatlake run & \multirow{3}{*}{ / } \\
\hline & $\begin{array}{c}\text { Physical fitness } \\
\text { training }\end{array}$ & $\begin{array}{c}\text { Auxiliary parallel bars with chest } \\
\text { arm support: } 8 * 3 \text { groups }\end{array}$ & \\
\hline & & Dumbbell walking 20 m: 4 groups & \\
\hline & $\begin{array}{l}\text { Classroom } \\
\text { content }\end{array}$ & Warm up gymnastics, volleyball & $\begin{array}{l}\text { Warm up } \\
\text { gymnastics, } \\
\text { volleyball }\end{array}$ \\
\hline \multirow[b]{2}{*}{4} & $\begin{array}{c}\text { Physical fitness } \\
\text { training }\end{array}$ & $\begin{array}{l}\text { Rope ladder training: three } \\
\text { groups of five movements }\end{array}$ & / \\
\hline & $\begin{array}{l}\text { Classroom } \\
\text { content }\end{array}$ & Warm up gymnastics, badminton & $\begin{array}{l}\text { Warm up } \\
\text { gymnastics, } \\
\text { badminton }\end{array}$ \\
\hline \multirow{4}{*}{5} & Physical fitness & $\begin{array}{l}\text { Rope ladder training: three } \\
\text { groups of five movements }\end{array}$ & \multirow{3}{*}{ / } \\
\hline & training & Lunge: 20 steps * 4 groups & \\
\hline & & Back up: $15 * 4$ groups & \\
\hline & $\begin{array}{l}\text { Classroom } \\
\text { content }\end{array}$ & $\begin{array}{c}\text { Warm up exercise } \\
\text { gymnastics, table tennis }\end{array}$ & $\begin{array}{c}\text { Warm up exercise } \\
\text { gymnastics, } \\
\text { table tennis } \\
\end{array}$ \\
\hline \multirow{3}{*}{6} & & Interval run & \multirow[b]{2}{*}{ / } \\
\hline & training & $\begin{array}{c}\text { Auxiliary chest and arm support } \\
\text { on parallel bars: } 8 * 3 \text { groups }\end{array}$ & \\
\hline & $\begin{array}{c}\text { Classroom } \\
\text { content }\end{array}$ & Warm up exercise gymnastics, Tai Chi & $\begin{array}{l}\text { Warm up exercise } \\
\text { gymnastics, Tai Chi }\end{array}$ \\
\hline \multirow{3}{*}{7} & & Standing jump: $15 * 4$ groups & \multirow[b]{2}{*}{ / } \\
\hline & training & $\begin{array}{c}\text { Auxiliary parallel bar arm } \\
\text { support: } 8 * 4 \text { groups }\end{array}$ & \\
\hline & $\begin{array}{l}\text { Classroom } \\
\text { content }\end{array}$ & Warm up gymnastics, cross-country & $\begin{array}{c}\text { Warm up } \\
\text { gymnastics, } \\
\text { cross-country }\end{array}$ \\
\hline \multirow[b]{2}{*}{8} & \begin{tabular}{|c|} 
Physical fitness \\
training
\end{tabular} & Auxiliary pull up: $8 * 6$ groups & / \\
\hline & $\begin{array}{l}\text { Classroom } \\
\text { content }\end{array}$ & Warm up gymnastics, shot put & $\begin{array}{l}\text { Warm up } \\
\text { gymnastics, } \\
\text { shot put }\end{array}$ \\
\hline
\end{tabular}

physical health evaluation scores of all the students fluctuated up and down, and there was no significant increase or decrease. Therefore, to sum up, the results can show that the physical fitness training program is added into the physical education curriculum, and the students receive the guidance of physical fitness training from professionals, which can effectively improve the comprehensive physical health level of students, and have a positive effect on the physical health of students.

\section{CONCLUSIONS}

The health problems of college students cannot be ignored. In order to enhance the physical quality of college students, physical education is set as a compulsory course in Colleges and Universities. Although physical fitness training has been widely recognized in the international community, whether it is necessary to integrate physical fitness training into college physical education curriculum has always been a hot topic. In this study, 20 students of grade 2019 in X university were selected as the experimental objects. In the first half of the academic year of

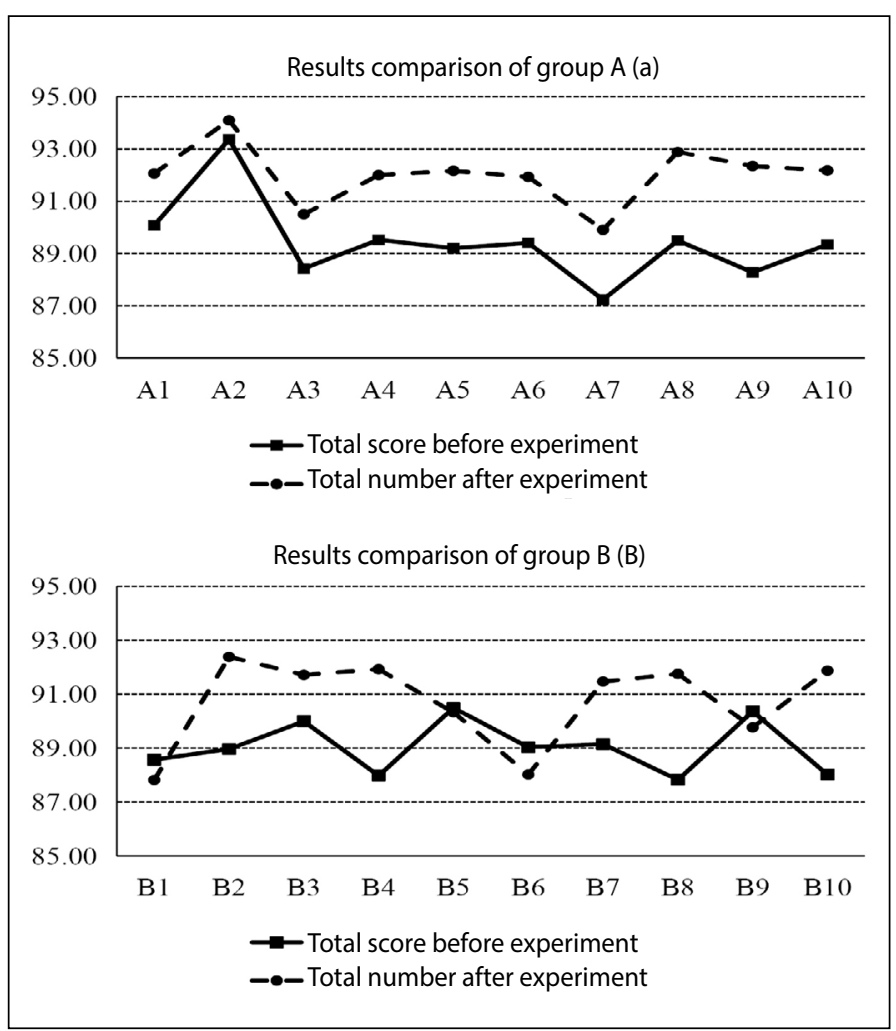

Figure 1. Comprehensive contrast chart of students' physical health score before and after the experiment.

Table 2. Statistical results of the experiment.

\begin{tabular}{|c|c|c|c|c|c|c|c|c|c|c|c|c|c|}
\hline & & & BMI index & $\begin{array}{l}\text { Body } \\
\text { density }\end{array}$ & $\begin{array}{c}\text { Vital } \\
\text { capacity }\end{array}$ & $\begin{array}{c}\text { Cardiac } \\
\text { function } \\
\text { index }\end{array}$ & $\begin{array}{c}\text { long- } \\
\text { distance } \\
\text { run }\end{array}$ & Grip & Pull up & $\begin{array}{c}\text { Standing } \\
\text { long jump }\end{array}$ & Sit forward & Total score & $\begin{array}{c}\text { Total } \\
\text { weighted } \\
\text { score } \\
\end{array}$ \\
\hline \multirow{3}{*}{ Group A } & $\mathrm{A} 1$ & Front & 97 & 79 & 80 & 87 & 90 & 90 & 79 & 97 & 97 & 796 & 90.08 \\
\hline & \multirow{2}{*}{$A 2$} & Front & 100 & 85 & 81 & 92 & 94 & 92 & 86 & 100 & 99 & 829 & 93.37 \\
\hline & & After & 100 & 85 & 83 & 95 & 96 & 95 & 85 & 100 & 100 & 839 & 94.10 \\
\hline \multirow{5}{*}{ Group B } & \multirow{2}{*}{ B1 } & Front & 91 & 95 & 83 & 81 & 79 & 91 & 89 & 90 & 90 & 789 & 92.18 \\
\hline & & After & 89 & 91 & 82 & 82 & 81 & 95 & 88 & 92 & 89 & 789 & 88.57 \\
\hline & \multirow{2}{*}{ B2 } & Front & 90 & 91 & 80 & 83 & 78 & 79 & 94 & 93 & 95 & 783 & 87.82 \\
\hline & & After & 96 & 89 & 90 & 80 & 81 & 90 & 90 & 96 & 97 & 809 & 88.97 \\
\hline & B3 & Front & 90 & 92 & 81 & 82 & 85 & 88 & 95 & 92 & 96 & 801 & 92.38 \\
\hline
\end{tabular}


2019-2020, the changes of College Students' physical health level under the introduction of physical fitness training into college physical education curriculum and the original physical education teaching mode were compared and analyzed. Due to the limitation of experimental funds and time, the number of subjects selected in this study is small. It will be the next research task to expand the selection range of experimental objects, increase the number of experimental objects, and continue to study the impact of physical fitness into college students' physical education curriculum on College Students' physical health level.

All authors declare no potential conflict of interest related to this article

AUTHORS' CONTRIBUTIONS: The author has completed the writing of the article or the critical review of its knowledge content. This paper can be used as the final draft of the manuscript. Every author has made an important contribution to this manuscript. Youfeng Yang: writing and execution. Wei Liu: data analysis.

\section{REFERENCES}

1. Vanhelst Jérémy, Béghin Laurent, Fardy PS, Zekya UImer, Grégory Czaplicki. Reliability of health-related physical fitness tests in adolescents: the MOVE Program. Clinical Physiology \& Functional Imaging, 2016, 36(2):106-111.

2. Brissman M, Ekbom K, Hagman E, Staffan Mårild, Eva Gronowitz, Carl-Erik Flodmark, Torsten Olbers, Claude Marcus. Physical Fitness and Body Composition Two Years after Roux-En-Y Gastric Bypass in Adolescents. Obesity Surgery, 2017, 27(2):1-8.

3. Wilks C R, Auerbach R P, Alonso J, Corina Benjet, Ronny Bruffaerts, Pim Cuijpers, David D. Ebert, Jennifer G. Green, Claude A. Mellins, Philippe Mortier, Ekaterina Sadikova, Nancy A. Sampson, Ronald
C. Kessler. The importance of physical and mental health in explaining health-related academic role impairment among college students. Journal of Psychiatric Research, 2020, 123(4):54-61.

4. Waure CD, Soffiani V, Poscia A. Physical activity and health promotion in Italian university students. Annali Dellistituto Superiore Di Sanita, 2015, 51(2):106-10.

5. Martinez Y T S, Harmon B E, Nigg C R, Erin O Bantum, Shaila Strayhorn. Diet and Physical Activity Intervention Strategies for College Students. Health Behavior \& Policy Review, 2016, 3(4):336.

6. Peer J W, Hillman S B, Van Hoet E. The Effects of Stress on the Lives of Emerging Adult College Students: An Exploratory Analysis. Adultspan Journal, 2015, 14(2):90-99. 